\title{
Akut Kompartman Sendromunun Nadir Görülen Bir Sebebi: Kırım-Kongo Kanamalı Ateşi
}

\author{
Acute Compartment Syndrome: \\ Crimean-Congo Haemorrhagic Fever
}

Özlem Yılmaz Taşdelen, Hatice Bodur, Meryem Dedeoğlu, Ümit Gafuroğlu Ankara Numune Eğitim ve Araştırma Hastanesi, Ankara, Türkiye

\section{Özet}

Akut ekstremite kompartman sendromu fasyalarla çevrili bir alandaki basıncın doku canlılı̆ı için gerekli perfüzyon basıncını bozacak kadar artması sonucu doku nekrozuna gidişle karakterize bir klinik durumdur. Çoğunlukla kırıklar ve yumuşak doku travmaları nedeniyle oluşur. Makalemizde nadir görülen bir sebeple önkolunda kompartman sendromu gelişen bir olgu sunuldu. Kırım-Kongo kanamalı ateşi son yıllarda ülkemizde de endemik olan, ateş ve kanamalarla seyreden mortalitesi ve bulaşıcılığı yüksek viral bir hastalıktır. Olgumuzda Kırım-Kongo kanamalı ateşinin seyri sırasındaki kanamalar nedeniyle kompartman sendromu gelişmiştir. (Türk Osteoporoz Dergisi 2013;19: 81-3)

Anahtar kelimeler: Kompartman sendromu, Kırım-Kongo kanamalı ateşi, nöropati

\section{Summary}

Acute extremity compartment syndrome is a clinical entity characterized by proceeding to tissue necrosis as a result of highly raised pressure within a fascial space causing a disruption of the perfusion pressure necessary for tissue viability. Mostly it is caused by fractures and soft tissue traumas. In this article a case with compartment syndrome in forearm which was developed by a rare cause was reported. CrimeanCongo haemorrhagic fever is a highly mortal and transmissible viral disease, characterized by fever and bleedings and is endemic in our country in recent years. The compartment syndrome was developed due to bleedings in the course of Crimean-Congo haemorrhagic fever in this case. (Turkish Journal of Osteoporosis 2013;19: 81-3)

Key words: Compartment syndrome, Crimean-Congo haemorrhagic fever, neuropathy

\section{Giriş}

Akut kompartman sendromu zamanında tanı konulup tedavisi yapılmadığında kalııı bozukluklara neden olabilecek önemli bir klinik sendromdur. Makalemizde nadir görülen bir sebeple kompartman sendromu gelişen bir olguyu sunmayı ve tartışmayı amaçladık. Olgumuzda Kırım-Kongo kanamalı ateşi (KKKA) nedeniyle yatırılarak tedavi edilen bir hastada kübital bölgeden venöz kan örneği alınmasını takiben önkolda kompartman sendromu gelişmiştir.

\section{Olgu}

Otuz sekiz yaşında, erkek, çiftçilikle uğraşan hasta KKKA tanısıyla hastanemiz enfeksiyon hastalıkları kliniğinde tedavi görmekte iken sol kübital bölgesinden venöz kan örneği alınmasını takiben bir iki saat içinde sol önkolu şişmiş, morarmış ve şiddetli ağrı başlamış. Ortopedi bölümü tarafından değerlendirilen hastada klinik bulgulara göre kompartman sendromu düşünülmüş ancak primer hastalığına bağlı koagülopatisi nedeniyle fasyotomi yapılamamış. Hipertonik sıvı emdirilmiş gazlı bezlerle lokal ödem tedavisi uygulanmıs. Antiviral ve destekleyici tedaviye yanıt veren hasta iyileşerek taburcu edilmiş. Taburculuğundan yaklaşık iki buçuk ay sonra kontrol muayenesine geldiğinde sol önkoldaki atrofisi ve güçsüzlüğü nedeniyle enfeksiyon hastalıkları bölümünce kliniğimize konsülte edildi.

Fizik muayenesinde sol önkolu ve eli atrofik, kırmızı- mor renkte idi ve terleme artışı vardı (Resim 1). Kas gücü muayenesinde el bileği ve el parmakları ekstansiyonu 4/5, el bileği ve el parmakları fleksiyonu 4/5, baş parmak abdüksiyonu 2/5, 5 . parmak abdüksiyonu 2/5, 1. parmak addüksiyonu $2 / 5$ gücünde idi. Önkolda hipoestezi, elde anestezi vardı. Elektronöromyografi (ENMG) incelemesi bölümümüzce yapıldı. Median ve ulnar sinirle innerve kaslarda denervasyon bulguları izlendi. Median ve ulnar sinirle innerve daha proksimal kaslarda istemli motor ünit potansiyelleri (MÜP) gözlenirken distal kaslarda istemli MüP elde edilemedi. Parmak-bilek segmentlerinde median ve ulnar 
duyusal aksiyon potansiyelleri (DAP) elde edilemedi. Triseps kası distalindeki radial sinirle innerve kaslarda denervasyon bulguları izlenirken interferans analizinde orta derecede seyrelme bulundu ve yüzeyel radial DAP amplitüdü küçülmüş olarak elde edildi. Elde edilen bulgular median ve ulnar sinirlerin ağır parsiyel lezyonu ve radial sinirin triseps kası innervasyonu distalinde hafif parsiyel lezyonu şeklinde yorumlandı.

Kliniğimiz el rehabilitasyonu ünitesinde tedavisine başlandı. Antideformite ateli verildi. Ekstremitenin elevasyonu, desensitizasyon, pasif ve aktif-asistif eklem hareket açıklığı egzersizleri ve güçlendirme egzersizlerini içeren rehabilitasyon programı yürütüldü. Olayın başlangıcından itibaren 6. ayda yapılan kontrol ENMG incelemesinde ulnar ve median sinirle innerve distal kaslarda rejenerasyon bulguları görüldü. Sekizinci ayında yapılan muayenesinde başparmak abdüksiyonu 4/5, adduksiyonu 3+/5, 5. parmak abdüksiyonu 4+/5, parmak ekstansiyonu 5-/5, el bileği ekstansiyonu 5-/5, el bileği fleksiyonu 4+/5 gücünde idi. 12. aydaki muayenesinde kas gücü muayenesi 8. aydaki gibi idi. 12. ayda elin görünümü Resim 2'de görülmektedir.

\section{Tartışma}

Kırım-Kongo Kanamalı Ateşi Afrika, Asya ve Güney-Doğu Avrupa'da otuzun üzerinde ülkede tanımlanmış ateş ve kanamalarla seyreden, mortalitesi yüksek, viral bir hastalıktır. 2002 yllından beri ülkemizde de Karadeniz bölgesinin güneyi ile iç Anadolu ve Doğu Anadolu bölgelerinin kuzey kesimleri

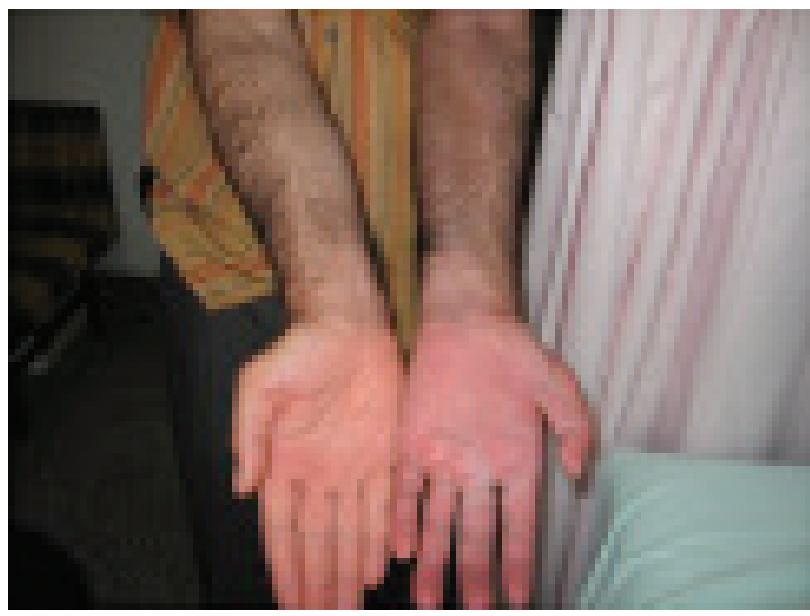

Resim 1. 2,5. aydaki sol önkol ve eldeki atrofiler ve renk değişikliği

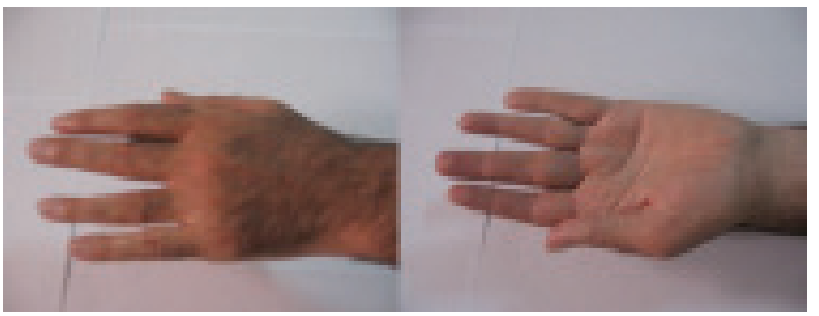

Resim 2. 12. ayda elin görünümü arasındaki geniş bir coğrafi alanda endemiktir. Hastalık genel olarak kendi kendini sınırlamakla birlikte kliniğin ağır seyrettiği olgularda doku ve organ kanamaları tabloya eklenebilir. Trombositopeni, hemostaz parametrelerinde bozulma ve bunlara bağı kanamalar görülür (1). Sağlık Bakanlığı verilerine göre ülkemizdeki kaba mortalite oranı $\% 5$ olarak bildirilmiştir (2). Bizim olgumuz kliniği ağır seyretmekle birlikte hayatta kalabilen hastalardan biriydi.

Akut ekstremite kompartmant sendromu fasyalarla sınırlı kapalı bir boşluktaki basıncın, kapiller perfüzyon basıncını doku canlıı̆̆ı için gerekli seviyenin altına düşürecek kadar artması olarak tanımlanmıştır (3). Zamanında tanınıp müdahale edilmezse kas ve sinir dokularında nekroz olur ve ilerleyen dönemde kaslarda fibrozis ve buna bağlı olarak ekstremitede kontraktür gelişir. Alt ekstremitelerde en sık anterior ve derin posterior kompartmanda üst ekstremitelerde ise önkol volar kompartmanında görülür (4). En sık nedenleri kırıklar ve yumuşak doku yaralanmalarıdır. (crush ya da künt) Bunlardan başka hemofiliye bağlı spontan hematom; ekstremitenin uzun süre basınç altında kalması (aşırı dozda ilaç alımı sonrası baygınlık vb nedenlerle); enfeksiyon, yanıklar, böcek ısırması, yılan sokmasına bağlı ödem ya da arteriyel yaralanma sonrası revaskülarizasyon yapıldığında oluşan ödem; uzun süren operasyonlarda ekstremitenin korunmasız pozisyonlanmasına bağlı olarak eksternal basıya maruz kalması; uzun süreli cerrahi turnike uygulanması ve antikoagülan kullananlarda vasküler ponksiyon sonrası gelişebilir (5).

Bizim olgumuzda başlatan olay KKKA nedeniyle koagülasyon bozukluğu olan bir hastada venöz kan örneği alınması idi. Literatürde KKKA'nın seyri sırasında kompartman sendromu gelişen iki olgu bildirilmiştir. 2005 ylında İran'dan bildirilen ilk olguda bizim hastamızda olduğu gibi sol kübital bölgeden kan alınmasını takiben sol önkolda kompartman sendromu gelişmiştir (6). Bundan başka her iki hastanın orta yaşlı, erkek ve çiftçi olmaları gibi ortak özellikleri vardı. İran'dan bildirilen olguda median ve ulnar nöropati gelişmiştir. Bizim olgumuzda radial nöropati de vardı. Yani bizim olgumuzda önkolda hem volar hem de dorsal kompartman tutulumu vardı. Moghtaderi KKKA hastalarında trombositopeni, koagülasyon bozukluğu ve de hastalık bulaşma riskinin yüksek olması nedenleri ile kompartman sendromu geliştiğinde cerrahi dekompresyon yapmanın imkansız olduğuna dikkati çekerek bu hastalarda kan alınmasını takiben uzun süreli bası uygulanması ve kanamanın devam edip etmediğinin iyice kontrol edilmesi gerektiğini bildirmiştir. Ek olarak zaten ekimotik olan bir ekstremiteden kan basıncı ölçümü yapılmasının da kanamayı başlatan sebep olabileceğini, bu konuda da dikkatli olunması gerektiğini vurgulamıştır (6).

İkinci olgu ülkemizden bildirilmiştir. On yedi yaşında, hayvancılıkla uğraşan kadın hastada KKKA sırasında oluşan kanamalar nedeniyle hem sağ üst hem de sol alt ekstremitede kompartman sendromu ve buna bağlı olarak sağ median ve ulnar, sol femoral nöropati geliştiği bildirilmiştir (7). Bizim olgumuzdan farklı olarak bu hastanın yatışı sırasında kompartman sendromu geliştiği fark edilememiş ve taburcu olduktan 6 ay sonra sağ el ve sol bacakta 
güçsüzlük şikayetiyle fizik tedavi ve rehabilitasyon bölümüne başvurduğunda yapılan elektrofizyolojik incelemeler ve MR görüntüleme ile KKKA hastalığının seyri sırasında kompartman sendromu geliştiği anlaşılmıştır.

Akut kompartman sendromunda tanı klinik muayene bulguları ile konur. Klinik belirti ve bulgular ilgili kompartmanda şişlik ve sertlik, ağrı (çoğunlukla mevcut yaralanmaya bağlı ağrı olması beklenen bölgeden başka bir yerde), ilgili kompartmanın pasif olarak gerilmesiyle ağrıda artma, duyu defisitleri ve motor güçsüzlüktür. Genellikle nabızlar alınır. Bilinci kapalı ya da bozuk olan hastalarda, çocuklarda, klinik bulgular şüpheli ise intrakompartmantal basınç (IKB) ölçümü ile de tanı konabilir. Erken tanı ve tedavi prognozu belirler. Tedavide varsa dış bası ortadan kaldırımalıdır. Fasyotomi yapılmalıdır (5). Bizım olgumuzda kanama bozukluğu olması nedeniyle fasyotomi yapılamamıştır. Kompartman sendromunda nöropatiler primer ve sekonder olarak gelişebilir. Erken dönemde iskemiye bağlı olarak primer ve geç dönemde kas kontraktürlerinin basısına bağlı olarak sekonder sebeple gelişebilir (5). Olgumuzda nöropatilerin nedeni kompartman sendomuna bağlı primer iskemik nöropati idi. Bununla beraber kompartman sendromunda kas ve sinir hasarı bir arada olduğundan güçsüzlüğün ne oranda nöropatiye ne oranda kas iskemi/nekrozuna bağlı olduğu tam olarak ayırt edilemeyebilir. Bu hastalarda elektrofizyolojik inceleme yapılırken bu durum da göz önünde bulundurulmalıdır.

Eğer etkilenen kasta fibrozis gelişirse kas kısalır, ekstremitede kontraktüre, deformiteye ve dolayısıyla disfonksiyona neden olur. Bu klinik Volkmann iskemik kontraktürü olarak tanımlanır (5).
Hastamızda erken dönemde başlanan rehabilitasyon programı ile cerrahi müdahale gerektirebilecek ciddi deformiteler ve fonksiyon kayıpları önlendi.

Sonuç olarak son dekatta ülkemizde de endemik hale gelen KKKA hastalığının seyri sırasında kompartman sendromu gelişebilir, eğer gelişirse hastada kanama bozukluğu olması nedeniyle fasyotomi yapılamayacağı için önleyici tedbirlerin alınması önemlidir. Bu hastalarda kan örneklemesinin mümkün olan en aza indirilmesi, kan alındıktan sonra uzun süre baskı uygulanması ve kanama olup olmadığının kontrol edilmesi gereklidir.

\section{Kaynaklar}

1. Bodur H. Kırım-Kongo kanamalı ateşi. Flora 2009;14:1-9.

2. Yilmaz GR, Buzgan T, Irmak H, Safran A, Uzun R, Cevik MA, et al. The epidemiology of Crimean-Congo haemorrhagic fever in Turkey, 2002-2007. Int J Infect Dis 2009;13:380-6.

3. Mubarak SJ, Hargens AR. Acute compartment syndromes. Surg Clin North Am 1983;63:539-65.

4. Azar FM. Traumatic disorders. In: Canale ST, Beaty JH editors. Campbell's Operative Orthopaedics. $11^{\text {th }}$ ed. Philadelphia, CN: Mosby; 2007. p. 2737-47.

5. Botte MJ, Gelberman RH. Compartment syndrome and ischemic contracture. In: Nickel VL, Botte MJ, editors. Orthopaedic rehabilitation. $2^{\text {nd }}$ ed. New York, CN: Churchill Livingstone Inc; 1992. p. 629-43.

6. Moghtaderi A, Alavi-Naini R, Azimi H. Compartment syndrome: an unusual course for a rare disease. Am J Trop Med Hyg 2005;73:450-2.

7. Uçan H, Açıl MM, Mandıroğlu S, Akyüz M, Hatipoğlu C. Median, ulnar and femoral neuropathy in a patient with Crimean-Congo hemorrhagic fever. Turk J Phys Med Rehab 2010;56:196-200. 